


\title{
PHOSPHATE ROCK APPLICATION ON ALFALFA (Medicago sativa L.) PRODUCTION AND MACRONUTRIENTS IN LATOSOL SOIL
}

\author{
Y. Liani ${ }^{1,2, *}$, Hu Hong-Qing ${ }^{1}$, Sumarsono ${ }^{2}$, D.W. Widjajanto ${ }^{2}$ and Jiang Guanjie ${ }^{1}$ \\ ${ }^{1}$ College of Resources and Environment, Huazhong Agricultural University, Wuhan 430070 - China \\ ${ }^{2}$ Faculty of Animal Agriculture, Diponegoro University, Semarang, Central Java - Indonesia \\ Corresponding E-mail: lianiy@yahoo.com
}

Received October 20, 2011; Accepted Nopember 29, 2011

\begin{abstract}
ABSTRAK
Penelitian dilakukan untuk mengetahui pengaruh aplikasi batuan fosfat pada produksi dan kandungan makronutrien alfalfa dibandingkan dengan pupuk fosfat kimia. Penelitian menggunakan rancangan acak lengkap yang berpola faktorial $3 \times 3$. Faktor pertama adalah sumber pupuk $\mathrm{P}$ yang berbeda: Guizhou Phosphate Rock (GPR), Jingxiang Phosphate Rock (JPR), dan Single Super Phosphate (SSP). Faktor kedua adalah dosis pupuk P: 75, 100, dan $125 \mathrm{mg} \mathrm{P}_{2} \mathrm{O} 5 / \mathrm{kg}$ tanah. Perlakuan kontrol (tanpa penambahan pupuk P, CK) telah ditambahkan sebagai perbandingan dengan perlakuan. Hasil menunjukkan bahwa produksi alfalfa tertinggi dihasilkan dari penambahan JPR, dimana GPR dan SSP menghasilkan kandungan nutrien lebih tinggi pada alfalfa disbanding dengan JPR. Kesimpulan dari penelitian ini adalah aplikasi batuan fosfat memiliki efek yang sama pada pertumbuhan alfalfa dibandingkan dengan SSP pada kondisi perlakuan tersebut.
\end{abstract}

Kata kunci: alfalfa, batuan fosfat, makronutrien, produksi

\begin{abstract}
The objective of this study was to evaluate the effectiveness of phosphate rocks (PRs) fertilizer compared to chemical $\mathrm{P}$ fertilizer for the best crop production and macronutrients of alfalfa. A completely randomized design under $3 \times 3$ factorial patterns was used in this research. The first factor was different sources of P fertilizer: Guizhou Phosphate Rock (GPR), Jingxiang Phosphate Rock (JPR), and Single Super Phosphate (SSP). The second factor was level of P fertilizer: 75, 100, and $125 \mathrm{mg}$ $\mathrm{P}_{2} \mathrm{O}_{5} / \mathrm{kg}$ soil. A control treatment (without addition of $\mathrm{P}$ fertilizer, $\mathrm{CK}$ ) was added as a comparison with the treatments. The results showed that JPR was the best for alfalfa production, whereas GPR and SSP were better for nutrient content in the alfalfa tissue than JPR. On the whole, phosphate rocks had similar effect on alfalfa growth compared to SSP at the experimental conditions.
\end{abstract}

Keywords: alfalfa, macronutrients, phosphate rock, production

\section{INTRODUCTION}

Phosphorus (P) is one of the essential nutrients for plants, but the least available mineral nutrients to the plants in many cropping environments (Shenoy and Kalagudi, 2005). Although $\mathrm{P}$ is quite abundant in soil but it reacts readily with iron, aluminum and calcium to form insoluble compounds and only a small proportion is immediately available to plants (Hinsinger, 2001; Lehmann et al., 2001; Richardson et al., 2009). The PRs are generally less water-soluble and slow release in soil, but it requires minimum processing and lower in cost per unit of $\mathrm{P}$, and effective under specific condition of soil management (Chien and Menon, 1995; Srivastava et al., 2007), so direct application of PRs to soil will help to reduce the cost of producing soluble $\mathrm{P}$ fertilizer and increase the crop production (Ahiabor and Hirata, 2003). Almost all of crops have a good yield response to chemical $\mathrm{P}$ fertilizer application, but the efficiency of phosphate rocks (PR) application varies greatly with plant species and mineralogical properties of PR (Jiang et al., 1990).

Alfalfa is one of the best forage among other feed crops (Markovic et al., 2009). Alfalfa is a kind of plant rich in protein, fiber, and mineral substances for animal nutrition, especially for ruminants (Katic et al., 2009). Forage crops are the sources of livestock nutrition, thus the management of forage crop production such 
alfalfa is important (Eskandari et al., 2009). Legume requires a large amount of $\mathrm{P}$ for symbiosis with rhizobia, so it is important to improve P acquisition (Graham and Vance, 2000). Many researches have been conducted to improve the alfalfa P-uptake, production and macronutrients with an adequate amount of chemical P fertilizer, but few data focus on direct application of PR to improve the alfalfa P-uptake, production and macronutrients in latosol soil. The objective of this study was to evaluate the effect of PRs application compared to chemical phosphate fertilizer on the best P-uptake, production and macronutrients of alfalfa in latosol soil.

\section{MATERIALS AND METHODS}

The latosol soil was collected from the top layer of 0-20 cm depth from Hainan Province, China for this experiment. The properties of latosol soil are shown at Table 1. Two sources of PRs were collected from Guizhou, China and Jingxiang, Hubei, China compared with chemical $\mathrm{P}$ fertilizer as SSP. The properties of PRs are shown at Table 2. Alfalfa (cv. Algonquin) was used as test crop to evaluate the effectiveness of PRs. USDA 1002 strain of Shinorbium meliloti was cultured in YMB (Yeast Manitol Brooth) liquid for inoculation.

A randomized factorial design $3 \times 3$ was used in this research. The first factor was different sources of P fertilizer: GPR, JPR, and SSP. The second factor was level of $P$ fertilizer: 75, 100, $125 \mathrm{mg} \mathrm{P}_{2} \mathrm{O}_{5} / \mathrm{kg}$ soil (Table 3). A control treatment (without addition of $\mathrm{P}$ fertilizer, $\mathrm{CK}$ ) was added as a comparison with the treatments.

Latosol soil was put in plastic pots as 5 $\mathrm{kg} /$ pot. P fertilizers were applied to the soil as the treatments, $\mathrm{N}$ and $\mathrm{K}$ fertilizer were applied in the same amount $(0.15 \mathrm{~g} / \mathrm{kg})$ as basal fertilizer for all treatments as urea and $\mathrm{KCl}$ including $\mathrm{CK}$. Five plants of alfalfa per pot were grown in a green house. Pots were inoculated with $5 \mathrm{~mL} /$ plant of YMB liquid medium containing Shinorbium meliloti at two weeks after sowing. The plants were grown in summer for 4 months (early May early September). The plants were watered everyday to keep the moisture at $70 \%$ of field water capacity.

The plant samples were separated into leaves and stems. The fresh and dry plant samples were weighed for dry matter yield (DMY). The plant
Table 1. Latosol Soil Properties

\begin{tabular}{lc}
\hline \multicolumn{1}{c}{ Properties } & Amount \\
\hline $\mathrm{pH}$ & 6.06 \\
Organic Carbon $(\mathrm{g} / \mathrm{kg})$ & 14.35 \\
Sand $(2-0.05 \mathrm{~mm})(\%)$ & 26.43 \\
Silt $(0.05-0.002 \mathrm{~mm})(\%)$ & 28.77 \\
Clay $(<0.002 \mathrm{~mm})(\%)$ & 44.80 \\
Total N $(\mathrm{g} / \mathrm{kg})$ & 1.11 \\
Available N $(\mathrm{mg} / \mathrm{kg})$ & 69.61 \\
Total P $(\mathrm{g} / \mathrm{kg})$ & 1.23 \\
Available P $(\mathrm{mg} / \mathrm{kg})$ & 24.56 \\
Total K $(\mathrm{g} / \mathrm{kg})$ & 0.90 \\
Available K $(\mathrm{mg} / \mathrm{kg})$ & 209.5 \\
CEC $(\mathrm{Cmol} / \mathrm{kg})$ & 17.07 \\
\hline
\end{tabular}

Table 2. The Properties of Phosphate Rocks (PR)

\begin{tabular}{lcc}
\hline Compounds & $\begin{array}{c}\text { Guizhou PR } \\
\text { (GPR) }\end{array}$ & $\begin{array}{c}\text { Jingxiang } \\
\text { PR (JPR) }\end{array}$ \\
\hline $\mathrm{P}_{2} \mathrm{O}_{5}(\%)$ & 35.6 & 23.2 \\
$\mathrm{CaO}(\%)$ & 52.0 & 38.1 \\
$\mathrm{Fe}_{2} \mathrm{O}_{3}(\%)$ & 0.20 & 38.5 \\
$\mathrm{Al}_{2} \mathrm{O}_{3}(\%)$ & 0.20 & 0.109 \\
$\mathrm{MgO}(\%)$ & 0.30 & 1.46 \\
$\mathrm{~Pb}(\mathrm{mg} / \mathrm{kg})$ & $*$ & 18.9 \\
$\mathrm{Cu}(\mathrm{mg} / \mathrm{kg})$ & $*$ & 13.8 \\
$\mathrm{Zn}(\mathrm{mg} / \mathrm{kg})$ & $*$ & 20.1 \\
$\mathrm{Cd}(\mathrm{mg} / \mathrm{kg})$ & $*$ & $*$ \\
Available $\mathrm{P}(\%)$ & 7.20 & 2.6 \\
\hline
\end{tabular}

*: below detection limit

biomass of each part were oven dried at $60-70{ }^{\circ} \mathrm{C}$ and ground into fine powder using mechanical grinder then digested with $\mathrm{H}_{2} \mathrm{SO}_{4}$ and $\mathrm{H}_{2} \mathrm{O}_{2}$ for $\mathrm{N}$, $\mathrm{P}, \mathrm{K}$ analysis. $\mathrm{P}$ content was analyzed using ultraviolet-visible spectrometer, and $\mathrm{N}$ concentration was determined by automatic nitrogen analyzer (Hanon K9840) and K content was estimated by flame photometer. The dry matter yield and the $\mathrm{P}$ concentration in plant tissues were used to calculate the P-uptake (Prochnow et al., 2006).

\section{Statistical Analysis}

The data were analyzed statistically by analysis of variance using SAS software. The 
Table 3. The Doses of Phosphate Fertilizers Applied (g/pot)

\begin{tabular}{lccc}
\hline \multicolumn{1}{c}{ Sources of } & \multicolumn{3}{c}{ P Level $\left(\mathrm{mg} \mathrm{P}_{2} \mathrm{O}_{5} / \mathrm{kg}\right.$ soil $)$} \\
\cline { 2 - 4 } Phosphate Fertilizer & 75 & 100 & 125 \\
\hline Guizhou PR & 1.28 & 3.01 & 4.73 \\
Jingxiang PR & 3.54 & 8.32 & 13.11 \\
SSP & 0.83 & 1.96 & 3.08 \\
\hline
\end{tabular}

Table 4. The Growth of Alfalfa in Latosol Soil Affected by P Applied

\begin{tabular}{cccc}
\hline Treatment & Height of plant $(\mathrm{cm})$ & Number of Tillers & Number of Leaves \\
\hline CK & $69.30^{\mathrm{g}}$ & $27^{\text {ed }}$ & $886^{\text {cdef }}$ \\
GPR- 75 & $74.46^{\mathrm{f}}$ & $26^{\text {ef }}$ & $1110^{\text {bc }}$ \\
100 & $85.20^{\mathrm{c}}$ & $29^{\text {cde }}$ & $989^{\text {cd }}$ \\
125 & $85.13^{\mathrm{c}}$ & $36^{\mathrm{a}}$ & $955^{\mathrm{cde}}$ \\
JPR- 75 & $95.80^{\mathrm{a}}$ & $29^{\mathrm{bcd}}$ & $1394^{\mathrm{a}}$ \\
100 & $87.86^{\mathrm{b}}$ & $32^{\mathrm{b}}$ & $839^{\text {defg }}$ \\
125 & $82.83^{\mathrm{d}}$ & $27^{\mathrm{def}}$ & $633^{\mathrm{g}}$ \\
SSP- 75 & $88.18^{\mathrm{b}}$ & $24^{\mathrm{f}}$ & $718^{\mathrm{fg}}$ \\
100 & $79.64^{\mathrm{e}}$ & $27^{\mathrm{def}}$ & $742^{\mathrm{efg}}$ \\
125 & $82.82^{\mathrm{d}}$ & $31^{\mathrm{bc}}$ & $1219^{\mathrm{ab}}$ \\
\hline
\end{tabular}

Different superscript in the same column shows significant differences $(\mathrm{P} \leq 0.05)$

$*=$ significant

differences among treatments were compared by Duncan's Multiple Range Tests (DMRT).

\section{RESULTS AND DISCUSSION}

Alfalfa Production Used Different P Fertilizers

The alfalfa production was measured as growth and forage yield. Alfalfa growth was measured as plant height $(\mathrm{PH})$, number of tillers (NT) and number of leaves (NL). The mean data of each parameter are presented in Table 4. The different source of $\mathrm{P}$, level of $\mathrm{P}$ fertilizers and interaction between them had significant effect to PH and NT. PH significantly increased with P application as $5.16-26.50 \mathrm{~cm}$ more than $\mathrm{CK}$. The highest PH was $95.80 \mathrm{~cm}$ resulted by the JPR 75 . JPR 125 and SSP 100 resulted the same amount in NT compared to CK. The highest NT was resulted by GPR 125 . The average data showed that GPR, JPR, and SSP resulted the same NT, whereas 125 $\mathrm{P}$ level was better than 100 and $75 \mathrm{P}$ level. NL was not significantly affected by the different source of P fertilizers, but the level of P fertilizers and the interaction between two factors had significantly effect to NL. There was no significant different between JPR 75 and SSP 125 in NL (1394 and 1219, respectively). JPR was a good $\mathrm{P}$ fertilizer source for alfalfa growth in which resulted the highest $\mathrm{PH}$ and $\mathrm{NL}$ in the level 75. The higher P level of JPR application was not suggested due to it decreased the alfalfa growth. Although JPR is the low availability of $\mathrm{P}$ fertilizer source but at the low $\mathrm{P}$ fertilizer application it could increase alfalfa growth higher than GPR and SSP. GPR was needed in the highest $P$ level to increase PH and NT, whereas SSP was needed in the highest $\mathrm{P}$ level to increase NT and NL of alfalfa.

The fresh and dry yield in each part of the plant as leaf, stem and total are shown in Table 5. There was an interaction between source and level of $\mathrm{P}$ fertilizers for all yield parameters. The source and level of $\mathrm{P}$ fertilizers had no significant effect to stem and total fresh yield, and stem dry yield. Leaf and total dry yield were not significantly affected with the source of P fertilizers, whereas 
Table 5. The Yield of Alfalfa in Latosol Soil Affected by P Applied

\begin{tabular}{|c|c|c|c|c|c|c|}
\hline \multirow[t]{3}{*}{ Treatment } & \multicolumn{6}{|c|}{ Yield (g/pot) } \\
\hline & \multicolumn{2}{|c|}{ Leaf } & \multicolumn{2}{|c|}{ Stem } & \multicolumn{2}{|c|}{ Total } \\
\hline & fresh & dry & fresh & dry & fresh & dry \\
\hline CK & $17.06^{\mathrm{cd}}$ & $2.71^{\mathrm{ef}}$ & $22.74^{\mathrm{f}}$ & $4.59^{\mathrm{d}}$ & $39.80^{\text {de }}$ & $7.30^{\mathrm{d}}$ \\
\hline GPR- 75 & $18.98^{\mathrm{c}}$ & $3.56^{\text {cde }}$ & $29.41^{\mathrm{cd}}$ & $6.89^{\mathrm{bc}}$ & $48.39^{\mathrm{bc}}$ & $10.45^{\mathrm{c}}$ \\
\hline 100 & $17.58^{\mathrm{cd}}$ & $3.46^{\text {cde }}$ & $30.90^{c}$ & $7.33^{\mathrm{abc}}$ & $48.47^{\mathrm{bc}}$ & $10.79^{\mathrm{bc}}$ \\
\hline 125 & $16.54^{\mathrm{cd}}$ & $3.05^{\text {def }}$ & $30.48^{\text {cd }}$ & $6.80^{\mathrm{bc}}$ & $47.02^{\mathrm{bcd}}$ & $9.84^{c}$ \\
\hline JPR- 75 & $29.24^{\mathrm{a}}$ & $5.04^{\mathrm{a}}$ & $40.04^{a}$ & $8.20^{\mathrm{a}}$ & $69.27^{\mathrm{a}}$ & $13.24^{\mathrm{a}}$ \\
\hline 100 & $22.68^{\mathrm{bc}}$ & $4.20^{\mathrm{abc}}$ & $26.96^{\text {de }}$ & $6.83^{\mathrm{bc}}$ & $49.64^{\mathrm{b}}$ & $11.03^{\mathrm{bc}}$ \\
\hline 125 & $11.98^{\mathrm{d}}$ & $2.17^{\mathrm{f}}$ & $23.59^{\mathrm{ef}}$ & $5.39^{\mathrm{d}}$ & $35.57^{\mathrm{e}}$ & $7.56^{\mathrm{d}}$ \\
\hline SSP- 75 & $17.47^{\mathrm{cd}}$ & $3.13^{\mathrm{de}}$ & $23.63^{\mathrm{ef}}$ & $6.53^{\mathrm{c}}$ & $41.09^{\text {cde }}$ & $9.66^{c}$ \\
\hline 100 & $21.77^{\mathrm{bc}}$ & $3.97^{\mathrm{bcd}}$ & $29.65^{\mathrm{cd}}$ & $7.25^{\mathrm{abc}}$ & $51.42^{\mathrm{b}}$ & $11.22^{\mathrm{bc}}$ \\
\hline 125 & $27.24^{\mathrm{ab}}$ & $4.60^{\mathrm{ab}}$ & $35.98^{\mathrm{b}}$ & $7.65^{\mathrm{ab}}$ & $63.22^{\mathrm{a}}$ & $12.25^{\mathrm{ab}}$ \\
\hline
\end{tabular}

Different superscript in the same column shows significant differences $(\mathrm{P} \leq 0.05)$.

$*=$ significant

the level of P fertilizers had no significant effect to leaf fresh yield. All of the treatments resulted the higher total fresh yield as 1.29-29.47 $\mathrm{g} / \mathrm{pot}$ than CK, except JPR 125 which was lower 4.24 $\mathrm{g} / \mathrm{pot}$ than CK. The total dry yield was higher than $\mathrm{CK}$ in all of treatments in the range 0.26-5.94 g/pot. Fresh and dry yield did not increase significantly with increasing P level of GPR, but decreased with increasing $P$ level of JPR either fresh or dry yield. However, fresh and dry yield were increased with increasing P level of SSP. There was no significant difference between JPR 75 and SSP 125 in increasing leaf and total fresh yield, but JPR 75 was better for increasing stem fresh yield than others. The best forage dry yield was resulted by JPR 75 and SSP 125 applications as 13.24 and $12.25 \mathrm{~g} / \mathrm{pot}$, respectively. There was no significantly different among them for increasing forage dry yield (leaf, stem and total).

Based on the result of plant growth and forage yield, its implied that JPR 75 resulted a good alfalfa production comparable with SSP, except for number of tiller. However, the higher level of JPR application decreased the alfalfa production. GPR also could increase the alfalfa production compared to $\mathrm{CK}$, but it was needed in the higher $\mathrm{P}$ level. Only a fraction $(30-50 \%$ of $\mathrm{P}$ dissolved from PR) becomes available for plant uptake because most of the P dissolved from PR goes through adsorption immediately and immobilization reactions (Bolan and Hedley, 1990). The interest in the use of phosphate rocks as an alternative source of $\mathrm{P}$ fertilizer has increased due to the relatively lower cost than the use of chemical $\mathrm{P}$ fertilizer and the potential of their utilization (Akande et al., 2010). Many researchers mentioned that $\mathrm{PR}$ application as $\mathrm{P}$ source with inoculation of Rhizobium was able to increase the performance of legume. Somado et al. (2003) observed that in both the pot and field experiments, there was a significant response of legume performance to PR application. Alfalfa responsed to $\mathrm{P}$ fertilizer application in latosol soil. In this study, plant growth and dry matter yield were markedly increased by phosphorus application with the different source of $\mathrm{P}$. According to research conducted by Barea et al. (2002), phosphate rock application improved plant growth and shoot biomass. The increasing $\mathrm{P}$ level of GPR resulted the same value on alfalfa production, it was likely caused by low PR solubility (Rick et al., 2011).

\section{Alfalfa Macronutrients}

The alfalfa leaf nitrogen content (range 20.18-27.49 $\mathrm{g} / \mathrm{kg}$ ) was higher than the stem (range $8.36-11.83 \mathrm{~g} / \mathrm{kg}$ ). The different source and level of $\mathrm{P}$ fertilizers and the interaction between them had significant effect to nitrogen content in plant tissues, but there was no significant effect on nitrogen in stem with different source of $\mathrm{P}$ fertilizers. The highest leaf $\mathrm{N}$ content was 27.49 $\mathrm{g} / \mathrm{kg}$ obtained by JPR 125 which had no significant difference with JPR 100 as $26.61 \mathrm{~g} / \mathrm{kg}$. There was no significant difference between the treatments compared to the control for nitrogen content in stem. The highest stem $\mathrm{N}$ content values were in SSP 125, GPR 100 and CK (11.83, 11.31 and $10.94 \mathrm{~g} / \mathrm{kg}$, respectively). JPR was better in resulting the high $\mathrm{N}$ content in leaf than 
Table 6. Alfalfa Nutrients Content

\begin{tabular}{ccccccc}
\hline Treatment & \multicolumn{3}{c}{ Leaf } & \multicolumn{3}{c}{ Stem } \\
\cline { 2 - 7 } & $\mathrm{N}$ & $\mathrm{P}$ & $\mathrm{K}$ & $\mathrm{N}$ & $\mathrm{P}$ & $\mathrm{K}$ \\
\cline { 2 - 7 } & & & $-----\mathrm{g} / \mathrm{kg}----$ & & \\
\hline CK & $20.49^{\mathrm{d}}$ & $2.08^{\mathrm{e}}$ & $32.84^{\mathrm{bc}}$ & $10.94^{\mathrm{abc}}$ & $3.78^{\mathrm{c}}$ & $33.36^{\mathrm{abc}}$ \\
GPR-75 & $20.18^{\mathrm{d}}$ & $2.60^{\mathrm{cd}}$ & $26.76^{\mathrm{f}}$ & $10.44^{\mathrm{bc}}$ & $4.50^{\mathrm{b}}$ & $32.79^{\mathrm{abc}}$ \\
100 & $22.99^{\mathrm{c}}$ & $3.03^{\mathrm{c}}$ & $31.01^{\mathrm{cde}}$ & $11.31^{\mathrm{ab}}$ & $3.93^{\mathrm{c}}$ & $31.43^{\mathrm{de}}$ \\
125 & $20.49^{\mathrm{d}}$ & $3.00^{\mathrm{cd}}$ & $30.08^{\mathrm{de}}$ & $10.54^{\mathrm{bc}}$ & $5.23^{\mathrm{a}}$ & $32.33^{\mathrm{cd}}$ \\
JPR-75 & $26.06^{\mathrm{b}}$ & $3.52^{\mathrm{b}}$ & $36.18^{\mathrm{a}}$ & $10.16^{\mathrm{c}}$ & $3.87^{\mathrm{c}}$ & $32.65^{\mathrm{bc}}$ \\
100 & $26.61^{\mathrm{ab}}$ & $4.48^{\mathrm{a}}$ & $32.15^{\mathrm{bcd}}$ & $10.80^{\mathrm{abc}}$ & $4.45^{\mathrm{b}}$ & $33.49^{\mathrm{ab}}$ \\
125 & $27.49^{\mathrm{a}}$ & $4.18^{\mathrm{a}}$ & $32.35^{\mathrm{bcd}}$ & $10.69^{\mathrm{bc}}$ & $4.52^{\mathrm{b}}$ & $33.52^{\mathrm{ab}}$ \\
SSP-75 & $21.44^{\mathrm{d}}$ & $3.63^{\mathrm{b}}$ & $28.95^{\mathrm{ef}}$ & $8.36^{\mathrm{d}}$ & $4.42^{\mathrm{b}}$ & $30.58^{\mathrm{e}}$ \\
100 & $23.22^{\mathrm{c}}$ & $4.22^{\mathrm{a}}$ & $33.96^{\mathrm{ab}}$ & $10.53^{\mathrm{bc}}$ & $5.13^{\mathrm{a}}$ & $32.91^{\mathrm{abc}}$ \\
125 & $23.74^{\mathrm{c}}$ & $2.54^{\mathrm{d}}$ & $31.54^{\mathrm{bcd}}$ & $11.83^{\mathrm{a}}$ & $4.55^{\mathrm{b}}$ & $33.85^{\mathrm{a}}$ \\
\hline & $*$ & $*$ & $*$ & $*$ & $*$ & $*$ \\
\hline
\end{tabular}

Different superscript in the same column shows significant differences $(\mathrm{p} \leq 0.05)$.

$*=$ significant

GPR and SSP, whereas GPR and SSP were better in resulting the high $\mathrm{N}$ content in stem than JPR.

The range values of phosphorus concentration in leaves were similar to the stems. The different source and level of $\mathrm{P}$ fertilizers and the interaction among them significantly affected the phosphorus concentration in both of alfalfa leaf and stem. There was a significant difference for $\mathrm{P}$ concentration between the treatments compared to control in both of leaf and stem. All of the $\mathrm{P}$ treatments could increase the $\mathrm{P}$ concentration in leaf compared to the CK. P concentration in leaf was $0.46-2.40 \mathrm{~g} / \mathrm{kg}$ higher with the $\mathrm{P}$ treatments than the $\mathrm{CK}$. The highest $\mathrm{P}$ concentration values in leaf were resulted by JPR 100, SSP 100, JPR 125 (4.48, 4.22, $4.18 \mathrm{~g} / \mathrm{kg}$, respectively). JPR and SSP were better than GPR in the level 75 and 100 of $\mathrm{P}$ fertilizer applied for resulting $\mathrm{P}$ concentration in the leaf tissue, but JPR was superior to GPR and SSP in the level 125 of $\mathrm{P}$ fertilizer applied for resulting P concentration in the leaf tissue. However SSP was better than GPR in the level 125 of P fertilizer applied for resulting $\mathrm{P}$ concentration increasing in the leaf tissue.

Table 6 showed that the range values of potassium concentration in leaves and stems were similar. The $\mathrm{P}$ treatments and the interaction between them have a significant effect to potassium in leaf and stem, but the level of $\mathrm{P}$ application had no significant effect to potassium content in leaf. The highest potassium contents in leaf were obtained by addition of JPR 75 and SSP
$100(36.18$ and $33.96 \mathrm{~g} / \mathrm{kg}$, respectively). There was no significant difference between the treatment compare to the control for potassium content in stem where the highest values were obtained by SSP 125, JPR 125, JPR 100 and control.

Crop species influenced the effect of $\mathrm{P}$ fixation on plant-available $\mathrm{P}$ from PR. The utilization of PR is more effective in legume than nonlegume crops (Rao et al., 1998). The higher plant has the ability to acquire the soluble nutrients from soil sparingly. When there is a demand of $\mathrm{P}$ by the shoot, the plants are able to compensate for inadequate $\mathrm{P}$ supply by expanding the root surface sorption area (Narang et al., 2000). Latosol soil tested contains $24.56 \mathrm{mg} / \mathrm{kg}$ of available $\mathrm{P}$ before $\mathrm{P}$ fertilizer application, this amount might be enough as a $\mathrm{P}$ starter for legume priming action in acidification process. Mallarino and Rueber (1997) suggested that PR could be valuable source of $\mathrm{P}$ to maintain desirable soil-test values for cropping systems that include forage legumes, it means that PR is suitable as $\mathrm{P}$ source for alfalfa

\section{CONCLUSION}

PR application in latosol soil was suitable for alfalfa $\mathrm{P}$-uptake, production and macronutrients content. P level $75 \mathrm{mg} \mathrm{P}_{2} \mathrm{O}_{5} / \mathrm{kg}$ soil was quite for alfalfa production in this soil. SSP was a good $\mathrm{P}$ source for alfalfa in latosol soil, although Guizhou and Jingxiang PR constitute P fertilizer sources 
comparable to SSP and therefore of great agronomic potentials. It should be pointed out that the present results were obtained in greenhouse pots that may differ from the actual field trials in different soil and plant species. The effect of PR application may have different responses in different soil type and crop species compare to chemical fertilizer.

\section{ACKNOWLEDGMENTS}

The research was supported by "Beasiswa Unggulan" scholarship program from Planning and Overseas Cooperation Bureau (BPKLN) Ministry of Education Republic of Indonesia. The authors are very grateful to Prof. Li Youguo for providing the Rhizobium.

\section{REFERENCES}

Ahiabor, B.D., and H. Hirata. 2003. Associative influence of soluble phosphate, rock phosphate and arbuscular mycorrhizal fungus on plant growth and phosphorus uptake of three tropical legumes. West African J. Applied Ecology. 4: 75-90

Akande, M.O., E.A. Makinde, F.I. Oluwatoyinbo, and M.T. Adetunji. 2010. Effects of phosphate rock application on dry matter yield and phosphorus recovery of maize and cowpea grown in sequence. African J. Environmental Sci. and Technology. 4(5): 293-303

Barea, J.M., M. Toro, M.O. Orozco, E. Campos, and R. Azcon. 2002. The application of isotopic $\left({ }^{32} \mathrm{P}\right.$ and $\left.{ }^{15} \mathrm{~N}\right)$ dilution techniques to evaluate the interactive effect of phosphatesolubilizing rhizobacteria, mycorrhizal fungi and Rhizobium to improve the agronomic efficiency of rock phosphate for legume crops. Nutrient Cycling in Agroecosystems. 63:35-42

Bolan, N.S., and M.J. Hedley. 1990. Dissolution of phosphate rocks in soil. 2. Effects of $\mathrm{pH}$ on the dissolution and plant availability of phosphate rock in soil with $\mathrm{pH}$ dependent charge. Fertilizer Research. 24:125-134.

Chien, S.H. and R.G. Menon. 1995. Factors affecting the agronomic effectiveness of phosphate rock for direct application. Fertilizer Research. 41:227-234.

Eskandari, H., A. Ghanbari, and A. Javanmard. 2009. Intercropping of cereals and legumes for forage production. Not. Sci. Biol. 1(1):713.

Graham, P.H., and C.P. Vance. 2000. Nitrogen fixation in perspective: an overview of research and extension needs. Field Crops Research. 65: 93-106.

Hinsinger, P. 2001. Bioavailability of soil inorganic $\mathrm{P}$ in the rhizosphere as affected by root-induced chemical changes: a review. Plant and Soil. 237:195-206.

Hinsinger, P. and R.J. Gilkes. 1997. Dissolution of phosphate rock in the rhizosphere of five plant species grown in an acid, P-fixing mineral substrate. Geoderma. 75:231-249

Jiang, Bai-fan, Lu Ru-kun and Li Ching-kwei. 1990. A review of the studies on phosphate rock for agricultural use in China. Fertilizer Research. 26:11-20

Katic, S., D. Milic, D. Karagic, S. Vasiljevic, D. Glamocic, and I. Jajic. 2009. Variation of protein, cellulose and mineral contents of Lucerne as influenced by cultivar and cut. Biotechnology in Animal Husbandry. 25(5-6): 1189-1195

Lehmann, J., M.S. Cravo, J.L.V. Macedo, A. Moreira, and G. Schroth. 2001. Phosphorus management for perennial crops in central Amazonian upland soils. Plant and Soil. 237: 309-319

Mallarino, A.P. and D. Rueber. 1997. Evaluation of superphosphate and rock phosphate for a corn-oat-forage rotation. Annual Progress Reports. p. 6-8. Markovic, J., R. Strbanovic, M. Cvetkovic, B. Andelkovic, B. Zivkovic. 2009. Effects of growth stage on the mineral concentrations in alfalfa (Medicago sativa $\mathrm{L}$.) leaf, stem and the whole plant. Biotech. in Anim. Husbandry. 25 (5-6): 1225-1231

Markovic, J., R. Strbanovic, M. Cvetkovic, B. Andelkovic, and B. Zivkovic. 2009. Effects of rowth stage on the mineral concentrations in alfalfa (Medicago sativa L.) leaf, stem and the whole plant. Biotechnology in Animal Husbandry. 25 (5-6): 1225-1231

Narang, R.A., Bruene A., and Aitmann T. 2000. Analysis of phosphate acquisition efficiency in Arabidopsis accessions. Plant Physiol. 124: 1786-1799

Prochnow, L.I., J.F.S. Quispe, E.A.B. Francisco, and G. Braga. 2006. Effectiveness of phosphate fertilizers of different water solubilities in relation to soil phosphorus adsorption. Sci. Agric. 63 (4): 333-340

Rao, M.R., A. Niang, F. Kwesiga, B. Duguma, S. Franzel, B. Jama, and R. Buresh. 1998. Soil fertility replenishment in sub-Sahara Africa: New techniques and the spread of their use on 
farms. Agroforestry Today. 10(2):3-8

Richardson, A.E., P.J. Hocking, R.J. Simpson, and T.S. George. 2009. Plant mechanisms to optimize access to soil phosphorus. Crop and Pasture Sci. 60:124-143

Rick, T.L., C.A. Jones, R.E. Engel, and P.R. Miller. 2011. Green manure and phosphate rock effects on phosphorus availability in a northern Great Plains dryland organic cropping system. Org. Agr. 1:81-90

Shenoy, V.V. and G.M. Kalagudi. 2005. Research review paper: Enhancing plant phosphorus use efficiency for sustainable cropping.
Biotechnology Advances. 23:501-513.

Somado, E.A., M. Becker, R.F. Kuehne, K.L. Sahrawat, and P.L.G. Vlek. 2003. Rice: Combined effects of legumes with rock phosphorus on rice in West Africa. Agron. J. 95:1172-1178

Srivastava, S., M.T. Kausalya, G. Archana, O.P. Rupela, and G. Naresh-Kumar. 2007. Efficacy of organic acid secreting bacteria in solubilization of rock phosphate in acidic alfisols. First International Meeting on Microbial Phosphate Solubilization. Springer. pp. 117-124 